\title{
PENDIDIKAN KARAKTER DI MADRASAH ALIYAH NEGERI (MAN) 2 BANJARMASIN
}

\author{
Burhanuddin Abdullah \\ Institut Agama Islam Negeri (IAIN) Antasari Banjarmasin \\ brhn_abdullab@yaboo.com \\ Radiansyah \\ Institut Agama Islam Negeri (IAIN) Antasari Banjarmasin \\ radi.ramalan@yaboo.com \\ Ali Akbar \\ Institut Agama Islam Negeri (IAIN) Antasari Banjarmasin \\ aliakbar_iain@yaboo.com
}

\begin{abstract}
The purpose of this study was to determine the role and responsibilities of teachers in implementing character building in Madrasah Aliyah Negeri 2 Banjarmasin. This study is a field research (field research) using descriptive qualitative approach. The population consisted of all teachers Madrasah Aliyah Negeri 2 Banjarmasin 62 people, and the sample 29 teachers in class XI. Methods of data collection in this study used the method of observation, interviews and documentation. The research result is the existence of sufficient learning facilities, extra-curricular activities. The participation of teachers in routine activities is required such as the implementation of the prayers in the mosque and spontaneous activities, such as giving sanction to students who are late, make slogans that can affect students for good character.
\end{abstract}

Keywords: Character Education, Moral Crisis, Task of the Teacher

\begin{abstract}
Abstrak
Tujuan penelitian ini adalah mengetabui peran dan tanggung jawab guru dalam melaksanakan pendidikan karakter di Madrasah Aliyah Negeri 2 Banjarmasin Penelitian ini adalab jenis penelitian lapangan (field research) dengan menggunakan pendekatan deskriptif-kualitatif. Populasi penelitian ini terdiri dari selurub guru Madrasah Aliyah Negeri 2 Banjarmasin yang berjumlah 62 orang, dan sampelnya 29 guru mata pelajaran kelas XI. Metode pengumpulan data dalam penelitian ini menggunakan metode observasi, wawancara dan dokumentasi. Hasil penelitian adalah adanya fasilitas belajar yang cukup, kegiatan extra kurikuler. Peran serta guru dalam kegiatan rutin seperti pelaksanaan shalat berjamaah di masjid dan kegiatan spontan, seperti memberi sanksi kepada siswa yang terlambat, membuat slogan-slogan yang dapat mempengarubi siswa untuk berkarakterbaik.
\end{abstract}

Kata kunci: Pendidikan Karakter, Krisis Moral, Tugas Guru.

Permalink/DOI: http://dx.doi.org/10.18326/infsl3.v9i2.537-560 


\section{Pendahuluan}

Pendidikan merupakan salah satu proses pengembangan sumber daya manusia yang perlu dikembangkan dan ditingkatkan dengan mendayagunakan sumber-sumber serta potensi yang ada.(Muslih Musa dan Aden Wijdan, 1997: 69). Pendidikan juga merupakan proses pembentukan kepribadian. Dengan pendidikan diharapkan dapat menghasilkan manusia yang berkualitas dan bertanggung jawab, (A. Fatah Yasin, 2008: 15). Salah satu pendidikan yang sangat penting bagi manusia sekarang ini dalam menghadapi era globalisasi dan kemajuan teknologi adalah pendidikan karakter. Munculnya gagasan program pendidikan karakter ini diawali oleh seringnya terjadi tindak kekerasan, korupsi, manipulasi, kebohongan, dan konflik. Tingginya angka kenakalan dan kurangnya sikap sopan santun, kerap tawuran, aksi pornografi, mengonsumsi narkotika, gemar berbohong, membolos sekolah, minum minuman keras, mencuri, berjudi kerap melanda anak didik. Oleh karena itu pendidikan harus menitik beratkan pendidikan karakter.

Nabi Muhammad kehadirannya di muka bumi ini membawa misi menyempurnakan akhlak mulia atau karakter sebagaimana sabda Nabi yang artinya. "Sesungguhnya aku diutus untuk menyempurnakan akhlak". Ada beberapa model pendidikan karakter yang dikembangkan di Indonesia, diantaranya:model pendidikan karakter berbasis ulul albab, pendidikan karakter berbasis prophetic intelligence, pendidikan karakter berbasis multikultural, pendidikan karakter berbasis 'ibad al-rabman. Berdasarkan latar belakang masalah itu, maka rumusan masalah penelitian ini adalah : Peran dan tanggung jawab guru dalam melaksanakan pendidikan karakter di Madrasah Aliyah Negeri 2 Banjarmasin serta Pendidikan karakter yang dirumuskan pada Madrasah Aliyah Negeri 2 Banjarmasin.

\section{Landasan Teori}

\section{Pengertian Pendidikan Karakter}

Karakter merupakan cara berpikir dan berperilaku yang menjadi ciri khas individu untuk hidup dan bekerjasama, baik dalam lingkup keluarga, masyarakat, bangsa dan negara. Menurut Hernowo (2004: 175) karakter adalah watak, sifat, atau hal-hal yang 
memang sangat mendasar yang ada pada diri seseorang. Selanjutnya Hernowo juga memberikan makna karakter sebagai tabiat dan akhlak atau budi pekerti yang membedakan seseorang dengan yang lain

Zubaedi (2011: 11) berpendapat bahwa Character is the sum of all the qualities that make you who you are. It's your values, your thoughts, your words, your actions. Artinya karakter adalah keseluruhan nilai-nilai, pemikiran, perkataan, dan perilaku atau perbuatan yang telah membentuk diri seseorang. Dengan demikian dapat dipahami, karakter adalah sifat, watak, tabiat, budi pekerti atau akhlak yang dimiliki oleh seseorang yang merupakan ciri khas yang dapat membedakan perilaku, tindakan dan perbuatan antara yang satu dengan yang lain. Menurut Bambang Q-Anees dan Adang Hambali (2008: 103) pendidikan karakter merupakan upaya untuk menanamkan karakter tertentu sekaligus memberi benih agar peserta didik mampu menumbuhkan karakter khasnya pada saat menjalani kehidupannya. Dengan demikian dapat dikatakan karakter mengacu kepada serangkaian sikap (attitudes), perilaku (behaviors), motivasi (motivations), dan keterampilan (skills). Dapat dikatakan bahwa pendidikan karakter adalah usaha untuk mendidik, menumbuhkan dan mengarahkan serta membentuk perilaku agar terbentuk perilaku atau akhlak mulia sesuai ajaran agama Islam, dalam hal ini adalah pembentukan karakter atau pribadi anak didik.

\section{Peranan Guru Dalam Pendidikan Karakter}

Guru adalah pendidik profesional dengan tugas utama mendidik, mengajar, membimbing, mengarahkan, melatih, menilai, dan mengevaluasi peserta didik pada pendidikan anak usia dini jalur pendidikan formal, pendidikan dasar, dan pendidikan menengah (UU No. 14 Tahun 2005 pasal 1 ayat 1). Ada empat kompetensi yang harus dimiliki oleh guru yakni kompetensi pedagogik, kompetensi kepribadian, kompetensi sosial, dan kompetensi profesional yang diperoleh melalui pendidikan profesi.

Guru adalah orang yang bertanggungjawab dalam melaksanakan pendidikan. Tugas pendidikan karakter tidak hanya dibebankan kepada guru tertentu saja misalnya guru agama tetapi 
merupakan tugas semua guru, Oleh sebab itu seorang guru harus memenuhi syarat-syarat tertentu serta memiliki sikap dan sifat-sifat yang baik.(M. Ngalim Purwanto, 1995: 139-148). Syarat itu antara lain berijazah, sehat jasmani dan rohani, bertanggung jawab, dan berjiwa nasional. Sedangkan sifat yang harus dimiliki antara lain adil, percaya, suka pada murid, sabar dan rela berkorban, memiliki wibawa (gezag), penggembira, menguasai dan suka kepada mata pelajaran yang diajarkan, dan berpengetahuan luas.

Guru minimal mempunyai tiga tugas pokok yaitu tugas profesional, tugas manusiawi, dan tugas kemasyarakatan. Di samping itu, Undang-undang Nomor 14 Tahun 2005 Pasal 10 ayat 1 menyatakan" Peranan guru dalam pengembangan pendidikan karakter di sekolah berkedudukan sebagai katalisator atau teladan, inspirator, motivator, dinamisator, dan evaluator. Dalam berperan sebagai katalisator, maka keteladanan seorang guru merupakan faktor mutlak dalam pengembangan pendidikan karakter peserta didik yang efektif, karena kedudukannya sebagai figur atau idola yang digugu dan ditiru oleh peserta didik. Peran sebagai inspirator berarti seorang guru harus mampu membangkitkan semangat peserta didik untuk maju mengembangkan potensinya. Peran sebagai motivator, mengandung makna bahwa setiap guru harus mampu membangkitkan spirit, etos kerja dan potensi yang luar biasa pada diri peserta didik. Peran sebagai dinamisator, bermakna setiap guru memiliki kemampuan untuk mendorong peserta didik ke arah pencapaian tujuan dengan penuh kearifan, kesabaran, cekatan, cerdas dan menjunjung tinggi spiritualitas.Sedangkan peran guru sebagai evaluator, berarti setiap guru dituntut untuk mampu dan selalu mengevaluasi sikap atau prilaku diri, dan metode pembelajaran yang dipakai dalam pengembangan pendidikan karakter peserta didik.

\section{Metode Guru dalam Membina Karakter Murid}

Dalam membina karakter anak, guru dapat menggunakan metode, antara lain:

1. Keteladanan

Seorang guru adalah seorang yang diharapkan menjadi teladan bagi murid-muridnya. Keteladanan adalah menempati posisi 
yang terpenting dalam pendidikan karakter anak. Setiap anak memiliki kecenderungan fitrah atau insting meniru. Kecenderungan fitrah yang terdapat pada diri anak akan mendorongnya untuk mencontoh perbuatan orang di sekitarnya. (Mahmud Mahdi Al Istambuli, 2006: 86).

\section{Pembiasaan}

Pembiasaan merupakan metode yang ampuh dalam membentuk tingkah laku murid agar bisa terbiasa melakukan hal-hal yang baik seperti disiplin memerlukan latihan agar menjadi kebiasaan yang tidak sulit untuk diwujudkan dalam diri murid. Pembiasan terhadap perbuatan baik bukanlah perkara yang mudah tapi diperlukan kesinambungan dan memakan waktu yang lama serta memerlukan kesabaran dalam penerapannya.

3. Pengawasan/Perhatian

Pengawasan merupakan kegiatan yang membantu dalam melaksanakan pembiasaan. Aturan atau larangan dapat berjalan dengan baik jika disertai dengan pengawasan yang terus menerus. Pengawasan merupakan usaha untuk selalu mengamati dan menjaga agar suatu perbuatan dilaksanakan dengan baik atau sesuai dengan aturan yang telah ditetapkan. Yang dimaksud dengan perhatian adalah senantiasa mencurahkan perhatian penuh dan mengikuti perkembangan aspek akidah dan moral anak, mengawasi dan memperhatikan kesiapan mental dan sosial, di samping selalu bertanya tentang situasi pendidikan jasmani dan kemampuan ilmiahnya. Islam memerintahkan kepada orang tua dan pendidik untuk memperhatikan dan senantiasa mengikuti serta mengawasi anak-anaknya dalam segala segi kehidupan dan pendidikan yang universal.

4. Perintah/Nasehat

Nasehat dan petuah memiliki pengaruh yang cukup besar dalam membuka mata anak-anak tentang kesadaran akan hakekat sesuatu, mendorong mereka menuju harkat dan martabat yang luhur, menghiasinya dengan akhlak yang mulia, serta membekalinya dengan prinsip-prinsip Islam. Karenanya tidak heran jika kita mengetahui bahwa AlQur'an menggunakan 
dan berulang-ulang dalam beberapa ayat dan dalam sejumlah tempat dimana Allah memberikan arahan dan nasehat-Nya.

5. Larangan/Ancaman

Metode tarhib diartikan suatu cara yang digunakan dalam pendidikan sebagai bentuk penyampaian hukuman atau ancaman kekerasan terhadap anak didik. Dengan adanya metode ini anak didik diharapkan akan jera dan meninggalkan hal-hal yang negatif karena merasa takut akan ancaman dan hukuman ynag akan diterimanya baik dari orang tua, guru maupun ancaman dari Allah kelak di hari akhirat.

6. Ganjaran/Imbalan

Ganjaran dalam konteks ini adalah memberikan sesuatu yang menyenangkan (penghargaan) dan dijadikan sebagai hadiah bagi peserta didik yang berprestasi, baik dalam belajar maupun sikap perilaku. Melalui ganjaran hasil yang dicapai peserta didik dapat dipertahankan dan meningkat, serta dapat menjadi motivasi bagi peserta didik lainnya untuk mencapai target pendidikan secara maksimal.

7. Hukuman

Hukuman adalah tindakan paling akhir diambil apabila teguran dan peringatan belum mampu untuk mencegah anak melakukan pelanggaran. Hukuman hakikatnya menurut pandangan para ilmuwan atau ahli pendidikan mempunyai kesamaan visi, yakni bahwa hukuman adalah sebagai alat untuk membentuk kepribadian anak sehingga anak tersebut mempunyai perasaan moral yang tinggi dengan demikian maka hukuman sama sekali tidak boleh dengan fisik tetapi dengan kasih sayang dan cinta.

\section{Metode Penelitian}

Penelitian ini adalah jenis penelitian lapangan (field research) dengan menggunakan pendekatan deskriptif-kualitatif. Penelitian ini dilakukan pada Madrasah Aliyah Negeri 2 Banjarmasin. 


\section{Populasi dan Sampel}

Populasi penelitian ini terdiri dari seluruh guru Madrasah Aliyah Negeri 2 Banjarmasin yang berjumlah 62 orang, sedangkan sampelnya semua guru mata pelajaran yang mengajar di kelas XI yang berjumlah 29 orang.

\section{Metode Pengumpulan Data}

Metode pengumpulan data dalam penelitian ini menggunakan metode observasi, wawancara dan dokumentasi.

\section{Analisa Data}

Analisis data dalam penelitian ini menggunakan Analisa Deskriptif, yang bertujuan untuk memperoleh informasi mengenai keadaan saat ini dan melihat kaitan antara variabel-variabel yang ada.

\section{Hasil Penelitian/Analisis}

\section{Gambaran Umum Lokasi Penelitian}

1. Sejarah MAN 2 Banjarmasin

Madrasah Aliyah Negeri 2 Banjarmasin adalah sekolah tingkat menengah sederajat SMU yang berciri khas Agama Islam di bawah Kementerian Agama. Madrasah ini dahulunya PGAN 6 tahun yang dialih fungsikan menjadi MAN pada tahun 1990, yang berlokasi di Jl.Mulawarman, namun karena sempit dan tidak memungkinkan untuk dikembangkan, maka sejak tahun 1984 dipindahkan ke Jl.Pramuka KM.6 Banjarmasin. Kemudian sejak tahun 1998 oleh Dirjen Pembinaan Kelembagaan Islam dijadikan sebagai MAN Model untuk kawasan Kalimantan Selatan. Pada Tahun 2005 MAN 2 Model Banjarmasin menerima penghargaan dari Pemerintah Daerah sebagai sekolah/madrasah berprestasi di bidang lingkungan hidup. Pada tahun 2006 menerima penghargaan sebagai Madrasah Berprestasi Tingkat Nasional oleh Dep.Agama RI Jakarta. Madrasah ini beralamat di Pramuka RT. 20 No. 28 Kelurahan Sungai Lulut Banjarmasin Timur 
Kota Banjarmasin.Telepon (0511) 3258164 - 3272819,(0511) 32727819.Madrasah ini telah terakreditasi dengan predikat A (sangat baik) berdasarkan Keputusan Menteri Agama NomorA/ Kw.17.4/4/PP.03.2/MA/08/2005.

2. Visi dan Misi MAN 2 Banjarmasin

Adapun visi MAN 2 ini adalah mewujudkan siswa yang Islami, berkualitas, terampil dan berdaya saing tinggi. Sedangkan misinya adalah sebagai berikut:

a. Menyelenggarakan pendidikan terpadu antara dunia dan akhirat

b. Menyelenggarakan pendidikan yang berorientasi mutu, berilmu, terampil, cerdas dan mandiri, sehingga mampu bersaing di dunia Internasional.

c. Menyelenggarakan pendidikan yang hasilnya memberikan kepuasan kepada masyarakat.Menyelenggarakan pendidikan dengan Manajemen Berbasis Madrasah (MBM) yang dapat dipertanggungjawabkan kepada publik.

3. Data Guru dan Siswa

Adapun guru-guru dan karyawan di MAN 2 Banjarmasin berjumlah 81 orang dengan rincian sebagai berikut:

\begin{tabular}{lllll}
\hline No & Guru/Karyawan & PNS & GTT/Honor & Jumlah \\
\hline 1 & Magister (S.2) & 6 & - & 6 \\
2 & Sarjana (S.1) & 45 & 10 & 55 \\
3 & Sarjana Muda & 1 & - & 1 \\
4 & Karyawan /TU & 9 & 10 & 19 \\
& Total & & & 81 \\
\hline
\end{tabular}


Sedangkan siswa-siswi di MAN 2 Banjarmasin berjumlah 978 sampai dengan Tahun Pelajaran 2012/2013 dengan rincian sebagai berikut:

\begin{tabular}{lllll}
\hline \multirow{2}{*}{ No } & $\begin{array}{c}\text { Tingkatan } \\
\text { Kelas }\end{array}$ & Laki-Laki & \multicolumn{1}{c}{$\begin{array}{c}\text { Siswa } \\
\text { Perempuan }\end{array}$} & Jumlah \\
\hline 1 & Kelas X & 132 & 222 & 354 \\
2 & Kelas XI & 169 & 194 & 363 \\
3 & Kelas XII & 101 & 160 & 261 \\
JUMLAH & JUMLAH & 402 & 576 & 978 \\
\hline
\end{tabular}

4. Kegiatan Ekstrakurikuler

Di samping kegiatan belajar mengajar yang dilaksanakan di kelas secara klasikal, ada beberapa kegiatan ekstra yang dilaksanakan di MAN 2 Banjarmasin, yaitu: keterampilan (Pilihan), meliputi komputer, elektronik, tata busana, otomotif dan tata boga, pramuka, PMR, drum band, muhadarah/pidato/puisi, rebana/ hadrah, musik panting, kaligrafi, teater, band, KIR, sepak bola, catur, pencak silat, bulu tangkis, tenis meja, basket, dan volly. Berdasarkan hasil angket yang dibagikan kepada guru-guru di MAN 2 Banjarmasin, khususnya guru-guru kelas XI, maka dapat ditemukan hasil sebagai berikut sebagaimana table-tabel di bawah ini:

\section{Tabel 1.}

Pengetahuan Guru Tentang Adanya Pembinaan Karakter Atau Akhlak Mulia Dalam Visi Dan Misi

\begin{tabular}{llll}
\hline No. & Alternatif Jawaban & Frekuensi & \multicolumn{1}{c}{ Persentasi } \\
\hline a. & Ada & 28 & 96,55 \\
b. & Tidak ada & - & - \\
c. & Ragu-ragu & - & - \\
d. & Tidak tahu/blanko & 1 & 3,45 \\
& J u m l a h & 29 & 100 \\
\hline
\end{tabular}

Hampir semua guru $(96,55 \%)$ mengakui bahwa dalam visi dan misi MAN 2 Model Banjarmasin terkandung pendidikan karakter 
atau pembinaan akhlak mulia, hanya satu orang guru yang tidak menjawab ada kemungkinan yang bersangkutan belum memahami akan visi dan misi sekolah jika dihubungkan dengan pendidikan karakter. Dari Tabel tersebut jelas sekali bahwa pemahaman guru dan tanggung jawab guru dalam pembinaan karakter dalam kategori sangat tinggi.

Tabel 2

\section{Persetujuan Guru Tentang Kewajiban Setiap Guru Membina Karakter Siswa}

\begin{tabular}{llll}
\hline No. & Alternatif Jawaban & Frekuensi & Persentasi \\
\hline a. & Ya/setuju & 27 & 93,1 \\
b. & Tidak setuju & - & - \\
c. & Ragu-ragu & 1 & 3,45 \\
d. & Tidak tahu/blanko & 1 & 3,45 \\
& J u m l a h & 29 & 100 \\
\hline
\end{tabular}

Dari tabel di atas terlihat hampir semua guru $(93,1 \%)$ menyadari bahwa setiap guru punya kewajiban untuk membina karakter. Hal ini berhubungan dengan pemahaman guru terhadap visi dan misi sekolah yang juga mengandung pembinaan karakter. Hanya satu orang yang masih ragu terhadap tugasnya sebagai pembina karakter dan satu orang lagi tidak menjawab. Kemungkinan besar yang bersangkutan belum memahami tugasnya sebagai guru dalam membina karakter siswa. Dari tabel ini dapat dipahami bahwa kesadaran guru terhadap tugasnya dalam membina karakter pada kategori sangat tinggi. 


\section{Tabel 3}

\section{Keterpanggilan Guru Membina Karakter Dalam Melaksanakan Tugas Sehari-Hari}

\begin{tabular}{llll}
\hline No. & Alternatif Jawaban & Frekuensi & Persentasi \\
\hline a. & Ya /terpanggil & 27 & 93,1 \\
b. & Tidak & - & - \\
c. & Ragu-ragu & 1 & 3,45 \\
d. & Tidak tahu/blanko & 1 & 3,45 \\
& J u m l a h & 29 & 100 \\
\hline
\end{tabular}

Pada tabel 3 ini menjelaskan komitmen guru terhadap tugasnya dalam membina karakter siswa. Pada tabel ini terlihat hampir semua guru $(93,1 \%)$ menyadari bahwa dalam tugasnya sehari-hari mereka terpanggil membina karakter siswa. Sama dengan tabel 2, ada satu orang yang masih ragu dan satu orang lagi tidak menjawab. Dapat dipahami bahwa yang komitmen terhadap tugasnya sebagai pembina karakter pada kategori sangat tinggi.

\section{Tabel 4}

Dalam Proses Pembelajaran Apakah Guru Selalu Menghubungkan Dengan Pembinaan Karakter

\begin{tabular}{llll}
\hline No. & \multicolumn{1}{c}{ Alternatif Jawaban } & Frekuensi & \multicolumn{1}{c}{ Persentasi } \\
\hline a. & Ya/selalu & 25 & 86,21 \\
b. & Kadang-kadang & 4 & 13,79 \\
c. & Jarang & - & - \\
d. & Tidak ada & - & - \\
& J u m l a h & 29 & 100 \\
\hline
\end{tabular}

Dari tabel di atas sebagian besar guru (86,21\%) menyatakan dalam proses pembelajaran selalu menghubungkan dengan pendidikan karakter. Hanya sedikit guru (13,79\%) kadang menghubungkannya, tidak ada mereka yang sama sekali tidak menghubungkannya dengan pendidikan karakter. Dari tabel ini bahwa tugas guru dalam menghubungkan proses pembelajaran dan pendidikan karakter pada kategori sangat tinggi. 


\section{Tabel 5}

Dalam Pembelajaran Apakah Guru Selalu Memberikan Nasehat Tentang Pembinaan Karakter

\begin{tabular}{llll}
\hline No. & Alternatif Jawaban & Frekuensi & Persentasi \\
\hline a. & Ya/selalu & 25 & 86,21 \\
b. & Kadang-kadang & 4 & 13,79 \\
c. & Jarang & - & - \\
d. & Tidak pernah & - & - \\
& J u m l a h & 29 & 100 \\
\hline
\end{tabular}

Pada tabel 5 ini terlihat kebanyakan guru (86,21\%) selalu memberi nasehat dalam proses pembelajaran dalam rangka membina karakter siswa, hanya sedikit guru $(13,79)$ yang kadangkadang memberi nasehat sewaktu proses pembelajaran. Tidak ada guru yang tidak pernah memberikan nasehat sewaktu proses pembelajaran. Pada kegiatan pemberian nasehat dalam proses pembelajaran berada pada kategori sangat tinggi.

\section{Tabel 6}

\section{Dalam Setiap Merencanakan Pelajaran Apakah Guru Selalu Menyisipkan Pembinaan Karakter}

\begin{tabular}{llll}
\hline No. & Alternatif Jawaban & Frekuensi & Persentasi \\
\hline a. & Ya & 18 & 62,07 \\
b. Kadang-kadang & 11 & 37,93 \\
c. Jarang & - & - \\
d. & Tidak pernah & - & - \\
& J u m l a h & 29 & 100 \\
\hline
\end{tabular}

Pada tabel ini terlihat lebih separo guru (62,07\%) selalu menyisipkan pembinaan karakter dalam perencanaan pelajaran, sebagian guru $(37,93 \%)$ kadang menyisipkan pendidikan karakter pada perencanaan pelajaran, tidak ada guru yang tidak pernah menyisipkan pembinaan karakter dalam perencanaan pelajaran. Jika digabung kedua kategori alternatif jawaban ini maka sikap guru ini termasuk dalam kategori sangat tinggi. 
Tabel 7

Pendapat/Persetujuan Guru Bahwa Setiap Guru Wajib

Memberi Contoh Tentang Karakter Yang Baik Walaupun

Bukan Guru Agama

\begin{tabular}{llll}
\hline No. & Alternatif Jawaban & Frekuensi & Persentasi \\
\hline a. & Ya/ setuju & 28 & 96,55 \\
b. & Tidak setuju & 1 & 3,45 \\
c. & Ragu-ragu & - & - \\
d. & Tidak tahu & - & - \\
& J u m 1 a h & 29 & 100 \\
\hline
\end{tabular}

Dalam tabel ini menunjukkan bahwa hampir semua guru (96,55\%) setuju bahwa setiap guru wajib memberikan contoh tentang karakter yang baik walaupun bukan guru agama, hanya satu orang yang tidak setuju dengan sikap tersebut. Dari sini dapat dipahami bahwa guru sangat menyadari akan tugasnya sebagai pembina pendidikan karakter yang selalu memberikan contoh yang baik kepada siswanya.

\section{Tabel 8}

Sikap Guru Jika Melihat Siswa Yang Bertingkah Laku Kurang Sopan

\begin{tabular}{llll}
\hline No. & Alternatif Jawaban & Frekuensi & Persentasi \\
\hline a. & Menegur & 29 & 100 \\
b. & Membiarkan & - & - \\
& J u m l a h & 29 & 100 \\
\hline
\end{tabular}

Dalam tabel ini terlihat semua guru (100\%) menegur apabila melihat siswanya yang bertingkah laku kurang sopan, tidak satupun guru yang membiarkan siswa bertingkah laku tidak sopan. Dari sini dapat dipahami bahwa sikap guru pada kategori sangat tinggi. 
Tabel 9

Dalam Membina Karakter Siswa, Adakah Usaha Bersama Guru-Guru Misalnya Mendiskusikannya

\begin{tabular}{llll}
\hline No. & Alternatif Jawaban & Frekuensi & Persentasi \\
\hline a. & Ya & 17 & 58,62 \\
b. & Kadang-kadang & 9 & 31,03 \\
c. & Jarang & 1 & 3,45 \\
d. & Tidak pernah & 2 & 6,90 \\
& J u m l a h & 29 & 100 \\
\hline
\end{tabular}

Pada tabel ini terlihat lebih separo guru $(58,62 \%)$ menyatakan bahwa mereka selalu berusaha membina karakter siswa secara bersamasama misalnya dengan mendiskusikannya. Ada sebagian guru (31,03\%) menyatakan kadang-kadang ada usaha bersama tersebut, sedikit sekali guru $(6,90)$ yang menyatakan tidak pernah mendiskusikannya. Jika digabung antara kategori a dan b maka usaha bersama guru dalam membina karakter siswa pada kategori sangat tinggi.

Tabel 10

Pendapat Guru Tentang Fasilitas Pembinaan Karakter

\begin{tabular}{llll}
\hline No. & Alternatif Jawaban & Frekuensi & Persentasi \\
\hline a. & Lengkap & 2 & 6,90 \\
b. & Cukup & 23 & 79,31 \\
c. & Kurang & 4 & 13,79 \\
d. & Tidak ada & - & - \\
& J u m l a h & 29 & 100 \\
\hline
\end{tabular}

Pada tabel ini terlihat beragam pendapat guru tentang fasilitas pembinaan karakter. Hanya sebagian kecil guru $(6,90)$ yang menyatakan fasilitas pembinaan karakter sudah lengkap. Sebagian besar guru $(79,31)$ menyatakan cukup saja dengan fasilitas yang ada. Hanya sedikit guru (13,79\%) guru yang menyatakan fasilitas pembinaan karakter kurang. Jika digabung antara kategori a dan b maka pendapat guru tentang cukupnya fasilitas berada pada kategori sangat tinggi. 
Tabel 11

Pendapat Guru Tentang Lingkungan Atau Situasi Kondisi Sekolah Dan Sekitarnya, Apakah Kondusif Dalam Pembinaan Karakter Siswa

\begin{tabular}{llll}
\hline No. & Alternatif Jawaban & Frekuensi & Persentasi \\
\hline a. & Baik & 15 & 51,72 \\
b. & Cukup & 11 & 37,93 \\
c. & Kurang & 2 & 6,90 \\
d. & Tidak baik & - & - \\
& J u m l a h & 29 & 100 \\
\hline
\end{tabular}

Dari tabel di atas terlihat separo lebih guru $(51,72 \%)$ menyatakan bahwa lingkungan atau situasi sekolah dalam kondisi baik untuk terciptanya pembinaan karakter siswa. Sebagian lagi menyatakan lingkungan dan situasi sekolah cukup kondusif untuk pembinaan karakter siswa, hanya sedikit guru (6,90\%) yang menyatakan lingkungan dan situasi sekolah kurang kondusif untuk pembinaan karakter siswa. Jika digabungkan antara kategori a dan b, maka pendapat guru yang menyatakan lingkungan kondusif untuk pembinaan karakter berada pada kategori sangat tinggi.

Tabel 12

Sikap Guru Jika Waktu Shalat Fardhu Tiba, Apakah Mengajak Shalat Berrjamah

\begin{tabular}{clll}
\hline No. & Alternatif Jawaban & Frekuensi & Persentasi \\
\hline a. & Selalu & 17 & 58,62 \\
b. & Sering & 12 & 41,38 \\
c. & Jarang & - & - \\
d. & Tidak pernah & - & - \\
& J u m l a h & 29 & 100 \\
\hline
\end{tabular}

Dari tabel di atas terlihat tentang sikap guru apabila waktu shalat tiba dalam hal ini tentu shalat zuhur. Lebih separo guru (58,62\%) menyatakan selalu mengajak siswa melaksanakan shalat berjamaah. Sebagian guru lainnya (41,38\%) menyatakan sering 
mengajak siswa melaksanakan shalat berjamaah. Tidak ada mereka yang menyatakan tidak pernah mengajak shalat berjamaah.Apabila digabung keduanya maka semua guru mengajak shalat berjamaah walaupun dalam frekuensi yang berbeda.

\section{Tabel 13}

Sikap Guru Tentang Disiplin Dalam Mengajar

\begin{tabular}{llll}
\hline No. & Alternatif Jawaban & Frekuensi & Persentasi \\
\hline a. & Selalu & 10 & 34,48 \\
b. & Sering & 19 & 65,52 \\
c. & Jarang & - & - \\
d. & Tidak pernah & - & - \\
& J u m l a h & 29 & 100 \\
\hline
\end{tabular}

Dari tabel di atas terlihat disiplin guru dalam mengajar. Sebagian guru $(34,48 \%)$ menyatakan selalu disiplin dalam mengajar atau tidak pernah tidak disiplin. Lebih separo guru $(65,52 \%)$ menyatakan sering berdisiplin dalam mengajar artinya jarang mereka tidak disiplin dalam mengajar. Dalam hal kedisiplinan ini maka posisinya pada kategori kurang.

Tabel 14

\section{Sikap Guru Dalam Menjawab Pertanyaan Siswa Yang Tidak Diketahui Jawabannya}

\begin{tabular}{llll}
\hline No. & Alternatif Jawaban & Frekuensi & Persentasi \\
\hline a. & Selalu & 9 & 31,03 \\
b. & Sering & 8 & 27,59 \\
c. & Jarang & 7 & 24,14 \\
d. & Tidak pernah & 5 & 17,24 \\
& J u m l a h & 29 & 100 \\
\hline
\end{tabular}

Dari tabel di atas terlihat keragaman sikap guru dalam merespon pertanyaan siswa yang tidak diketahui jawabannya. Jumlah terbanyak $(31,03 \%)$ adalah guru yang selalu menjawab setiap pertanyaan siswa walaupun tidak diketahui jawabannya. Kemudian disusul sebagian guru $(27,59 \%)$ yang sering menjawab pertanyaan 
siswa walaupun tidak diketahui jawabannya. Kemudian disusul lagi sebagian guru $(17,24 \%)$ yang jarang menjawab pertanyaan siswa walaupun tidak diketahui jawabannya. Dan paling sedikit $(17,24 \%)$ guru yang menyatakan tidak pernah menjawab pertanyaan murid yang tidak diketahui jawabannya. Dalam hal bisa dipahami bahwa pada kategori ini sikap guru sangat rendah.

Tabel 15

Sikap Guru Dalam Meminta Maaf Jika Terjadi Kekeliruan

\begin{tabular}{llll}
\hline No. & Alternatif Jawaban & Frekuensi & Persentasi \\
\hline a. & Selalu & 23 & 79,31 \\
b. & Sering & 5 & 17,24 \\
c. & Jarang & 1 & 3,45 \\
d. & Tidak pernah & - & - \\
& J u m l a h & 29 & 100 \\
\hline
\end{tabular}

Dari tabel di atas dapat dilihat tentang sikap guru apabila terjadi kekeliruan. Sebagian besar guru $(79,31 \%)$ menyatakan selalu meminta maaf jika terjadi kekeliruan, sebagian kecil $(17,29 \%)$ guru menyatakan sering minta maaf tapi kadang-kadang tidak minta maaf. Ada sedikit sekali yang jarang minta maaf (3,45\%). Dari sini dapat dipahami bahwa sikap minta maaf dari guru ini pada kategori tinggi.

\section{Tabel 16}

Sikap Guru Dalam Memberi Kesempatan Kepada Siswa Untuk Berdialog

\begin{tabular}{llll}
\hline No. & Alternatif Jawaban & Frekuensi & Persentasi \\
\hline a. & Selalu & 16 & 55,17 \\
b. & Sering & 11 & 37,93 \\
c. & Jarang & 2 & 6,90 \\
d. & Tidak pernah & - & - \\
& J u m l a h & 29 & 100 \\
\hline
\end{tabular}

Dalam tabel ini dapat dilihat sikap guru dalam memberikan siswa kesempatan untuk berdialog. Lebih separo guru $(55,17 \%)$ 
selalu memberikan kesempatan untuk berdialog. Sebagian guru $(37,93 \%)$ menyatakan sering berdialog dengan siswa artinya kadangkadang juga tidak memberikan kesempatan dialog. Sebagian kecil lagi $(6,90 \%)$ menyatakan jarang memberikan kesempatan siswa untuk berdialog. Jika digabungkan antara kategori a dan b maka kategorinya berada pada posisi sangat tinggi.

Tabel 17

Sikap Guru Dalam Memberikan Kesempatan Kepada Siswa Untuk Berfikir Agar Kecerdasan Mereka Terlatih

\begin{tabular}{llll}
\hline No. & Alternatif Jawaban & Frekuensi & Persentasi \\
\hline a. & Selalu & 11 & 37,93 \\
b. & Sering & 17 & 58,62 \\
c. & Jarang & - & - \\
d. & Tidak pernah/blanko & 1 & 3,45 \\
& J u m l a h & 29 & 100 \\
\hline
\end{tabular}

Dalam tabel di atas terlihat tentang sikap guru dalam memberikan keempatan siswa untuk berfikir agar kecerdasan mereka terlatih. Sebagian guru $(37,93 \%)$ selalu memberikan kesempatan kepada siswa untuk berfikir. Lebih separo guru $(58,62 \%)$ menyatakan sering atau kadang juga tidak memberi kesempatan untuk berfikir. Hanya satu orang yang tidak menjawab pertanyaan ini.Kalau dilihat dari sini jika digabungkan antara a dan b maka kategorinya berada pada tinggi sekali

Tabel 18

Sikap Guru Dalam Memberikan Nasehat Agar Siswa Sabar Dan Tangguh

\begin{tabular}{llll}
\hline No. & Alternatif Jawaban & Frekuensi & Persentasi \\
\hline a. & Selalu & 12 & 41,38 \\
b. & Sering & 16 & 55,17 \\
c. & Jarang & - & - \\
d. & Tidak pernah/blanko & 1 & 3,45 \\
& J u m l a h & 29 & 100 \\
\hline
\end{tabular}


Dalam tabel ini bisa dilihat tentang sikap guru dalam memberikan nasehat agar siswa sabar dan tangguh. Sebagian guru (41,38\%) menyatakan bahwa mereka selalu memberikan nasehat agar menjadi sabar dan tangguh. Lebih separo $(55,17 \%)$ mereka menyatakan sering memberi nasehat agar siswa sabar dan tangguh menghadapi cobaan dan rintangan. Namun ada sedikit guru $(3,45 \%)$ yang tidak menjawab. Kalau dilihat dari sini maka jika digabungkan kategori a dan b berada pada kategori sangat tinggi.

Tabel 19

Karakter Yang Sering Ditanamkan Oleh Guru

\begin{tabular}{llll}
\hline No. & Alternatif Jawaban & Frekuensi & Persentasi \\
\hline a. & Kereligiusan & 17 & 58,62 \\
b. & Kejujuran & 22 & 75,86 \\
c. & Kecerdasan & 11 & 37,93 \\
d. & Ketangguhan & 8 & 27,57 \\
e. & Kedemokratisan & 7 & 24,14 \\
f. & Kepedulian & 12 & 41,38 \\
g. & Lainnya ........... & - & - \\
& J u m l a h & 29 & 100 \\
\hline
\end{tabular}

Dari tabel di atas dapat diketahui karakter yang ditanamkan guru kepada siswa. Lebih separo guru (58,62\%) menanamkan karakter keagamaan. Sebagian besar guru $(75,86 \%)$ menanamkan kejujuran; sebagian guru (37,93\%) menanamkan kecerdasan; sebagian lagi $(27,57 \%)$ menanamkan ketangguhan; paling sedikit guru $(24,14 \%)$ menanamkan kedemokratisan; dan hampir separo guru $(41,38 \%)$ menanamkan kepedulian.

\section{Kesimpulan}

Karakter yang ingin dibentuk kepada siswa Madrasah Aliyah Negeri 2 Model Banjarmasin yaitu siswa yang Islami, berkualitas, terampil dan berdaya saing tinggi. Karakter ini diwujudkan melalui misi pendidikan terpadu antara dunia dan akhirat, yang berorientasi mutu, berilmu, terampil, cerdas dan mandiri, sehingga mampu bersaing di 
dunia Internasional, di samping mengembangkan dan memelihara nilai-nilai yang ada di madrasah, meliputi; Aqidah Islam, Akhlaqul Karimah, Nilai Ilmiah, Kekeluargaan, Kebersamaan, Mandiri, hemat, bertanggung jawab, Sederhana dan Kreatif.

Untuk mencapai tujuan tersebut ditunjang oleh fasilitas belajar yang cukup seperti laboratorium, masjid, serta fasilitas lainnya yang telah dipenuhi oleh MAN 2 Model Banjarmasin. Di samping itu ditunjang pula dengan kegiatan extra kurikuler berupa kegiatan pramuka dan olah raga. Adapun strategi yang dilaksanakan dalam pendidikan karakter di samping dilaksanakan dalam pembelajaran yang banyak diperankan oleh guru, juga dilakukan melalui kegiatan rutin seperti pelaksanaan shalat berjamaah pada waktu zuhur semua siswa wajib melaksanakannya di mesjid; melalui kegiatan spontan seperti memberi sanksi kepada siswa yang terlambat datang; melalui keteladanan dan pengkondisian seperti membuat slogan-slogan yang dapat mempengaruhi siswa untuk memiliki karakter yang baik.

Konsep pendidikan karakter yang dikembangkan di MAN 2 Model Banjarmasin sebagaimana dirumuskan dalam visinya, yaitu mewujudkan siswa yang Islami, berkualitas, terampil dan berdaya saing tinggi;Untuk mewujudkan visi tersebut semua guru telah berperan dalam tugasnya selaku pendidik yang bertanggungjawab terhadap pembinaan karakter siswa MAN 2 Model Banjarmasin serta telah ditunjang dengan fasilitas yang cukup.

\section{Daftar Pustaka}

Ahmadi, Abu dan Nur Uhbiyati.1991. Ilmu Pendidikan. cet. ke-1, Jakarta: Rineka Cipta

Ahwani al-, Ahmad Fu’ad. 1967. al-Tarbiyah fi al-Islam. cet. ke-2, t.tp.: Dar al-Ma'arif

Arifin, M. 1996. Filsafat Pendidikan Islam. cet. ke-5, Jakarta: Bumi Aksara

Buseri, Kamrani.2010. Pendidikan Keluarga. Banjarmasin: Lanting 
Media Aksara

Collins, Mallary M. dan Don Fotenelle. 1992. Mengubah Perilaku Siswa. Jakarta: PT. Bpk Gunung Mulia

Daradjat, Zakiah. 1996. Ilmu Jiwa Agama. Jakarta: Bulan Bintang .1998. Kepribadian Guru. cet. ke-2, Jakarta: Bulan Bintang. .1995.Pendidikan Islam dalam Keluarga dan Sekolah. cet. ke-2, Jakarta: Ruhama.

Darmadi, Hamid.2009. Dasar Konsep Pendidikan Moral, Landasan Konsep Dasar dan Implementasri. Bandung: Alfabeta.

Daulay, Haidar Putra.2004. Pendidikan Islam dalam Sistem Pendidikan Nasional di Indonesia. Jakarta: Kencana.

Departemen Pendidikan dan Kebudayaan Rl. 1991. Kamus Besar Bahasa Indonesia.cet. ke-1, Jakarta: Balai Pustaka.

Dirjen Kelembagaan Agama Islam Departemen Agama. 2005. Wawasan Tugas Guru dan Tenaga Kependidikan, Jakarta: t. p.

Elfindri, et.al. 2010. Soft Skills Unutk Pendidik.t.tp.: Baduose Media

Huda, Nuril, et.al. 2010. Pengembangan Model Evaluasi pada Pendidikan Akhlak Berbasis Prophetic Intelligence Bagi Mahasiswa IAIN Antasari Banjarmasin. Banjarmasin: Puslit IAIN Antasari.

Husaini, Rusdiana, et.al. 2010. Model Pembelajaran Pendidikan Agama Islam Berbasis Akhlak Mulia pada SMP Negeri I Kertak Hanyar Kabupaten Banjar (Penelitian Tindakan Kelas-Model Pembelajaran Kooperatif). Banjarmasin: Puslit IAIN Antasari.

Kahar, Masykur. 1994. Membina Moral dan Akhlak. Jakarta: Rineka Cipta.

Marimba, Ahmad D. 1974. Pengantar Filsafat Pendidikan Islam, cet. ke-3, Bandung: al-Ma'arif.

Munawwar al-, Said Agil Husin. 2005. Al-Qur'an Membangun Tradisi Kesalehan Hakiki. Jakarta: Ciputat Pers. 
Munawwir al-, Ahmad Warson, 1984. Kamus al-Munawwir ArabIndonesia. Surabaya: Pustaka Progressif.

Mursi, Muhammad Munir. al-Tarbiyah al-Islamiyah Ushuluha wa Tathawwuruha fi al-Bilad al-'Arabiyah. Kairo: Alam al-Kutub, t.th.

Musa, Muslih dan Aden Wijdan. 1997. Pendidikan Islam dalam Peradaban Industrial. Yogyakarta: Aditya Madia.

Nahlawi al-, Abd al-Rahman. 1995. Pendidikan Islam di Rumah, Sekolah dan Masyarakat. Jakarta: Gema Insani Press.

Nasir, M. Ridlwan. 2005. Mencari Tiplogi Format Pendidikan Ideal Pondok Pesantren di Tengah Arus Perubahan. Yogyakarta: Pustaka Pelajar.

Noeng, Muhajir. 1994. Metodologi Penelitian Kualitatif. Yogyakarta: UMY.

Pidarta, Made. 2007. Landasan Kependidikan, Stimulus Ilmu Pendidikan Bercorak Indonesia. Jakarta: Renika Cipta.

Poerwadarminta, W. J. S. 1982. Kamus Umum Bahasa Indonesia. Jakarta: Balai Pustaka

Purwanto, M. Ngalim, 1995. Ilmu Pendidikan Teoritis dan Praktis. Bandung: Remaja Rosdakarya.

Rakhmat, Jalaluddin. 1997. Psikologi Agama. cet. ke-2, Jakarta: Raja Grafendo Persada.

Salamah, "Pengembangan Model Pembelajaran Bidang Studi PAI untuk Meningkatkan Akhlak Siswa (Penelitian Reseach and Development pada SMU)". Jurnal "Khazanab" Volume III Nomor 06, tahun 2004.

Schaefer, Charles. 1989. Bagaimana Mempengaruhi Anak. Bandung: Dahara Frize. 
Shaleh, Abdul Rachman. 2006. Madrasah dan Pendidikan Anak Bangsa; Visi, Misi dan Aksi. Jakarta: PT. Raja Grafindo Persada

Shihab, Muhammad Quraish. 1998. Wawasan Al Qur'an. Bandung: Mizan.

. 1998. Mengungkap Tabir Ilahi Asmaul Husna dalam Persepektif al-Qur'an. Jakarta: Lentera Hati

Soyomukti, Nurani. 2010. Teori-teori Pendidikan. Yogyakarta: ArRuzz Media.

Sudarsono. 1993. Etika Islam tentang Kenakalan Remaja. Jakarta: Rineka Cipta.

Suyanto.Dinamika 2006. Pendidikan Nasional (Dalam Percaturan Dunia Global). Jakarta: PSAP Muhamadiyah.

Syah, Muhibbin. 1996. Psikologi Pendidikan. cet. ke-3, Bandung: Remaja Rosda Karya.

Tafsir, Ahmad. 1994. Ilmu Pendidikan dalam Perspektif Islam. cet. ke2, Bandung: Remaja Rosda Karya . 1997. Metodologi Pengajaran Agama Islam. cet. ke-3, Bandung: Remaja Rosda Karya

Uhbiyati, Nur. 1997. Ilmu Pendidikan Islam. cet. ke-2, Bandung: Pustaka Setia.

Ulwan, Abdullah Nashih. 1981. Pedoman Pendidikan Anak dalam Islam. cet. ke-3, Semarang: al-Syifa.

Undang-undang Nomor 14 Tahun 2005 Tentang Guru dan Dosen.

Walid, Muhammad, "Model Pendidikan Karakter di Perguruan Tinggi Agama Islam (Studi tentang Pendidikan Karakter Berbasis Ulul albab di Universitas Islam Negeri Maulana Malik Ibrahim Malang)" . Jurnal eL-QUDWAH - Volume 1 Nomor 5, edisi April 2011. 
Ya'qub, Hamzah. 1993. Etika Islam: Pembinaan Akhlakul Karimah. cet. ke-6, Bandung: CV. Diponegoro.

Yasin, A. Fatah. 2008. Dimensi-dimensi Pendidikan Islam, Malang: UIN Malang Press.

Yunus, Mahmud.1973. Kamus Arab-Indonesia. Jakarta: Yayasan Penyelenggara Penerjemah/Penafsiran al-Qur'an 